\title{
PENGUJIAN EFEKTIVITAS WAKTU PEMANGKASAN BUNGA JANTAN TERHADAP PENINGKATAN KOMPONEN HASIL DAN HASIL JAGUNG MANIS (Zea may L)
}

\section{Testing Of Effectiveness Of Time Of General Measurement Of Increasing Results Cemponents Aand Sweet Corn Products (Zea may L)}

\author{
Lia Amalia \\ Fakultas Pertanian Universitas Winaya Mukti \\ Lia8264@yahoo.com
}

\begin{abstract}
The research was conducted in experimental garden of Faculty of Agriculture Unwim which has a place to stay $850 \mathrm{mdpl}$. This study aims to determine the effective timing of male pruning to increase yield components and sweet corn yield. The environmental plan used is a collection of groups consisting of: $A=$ Without pruning $B=$ Pruning 7 days after pollination $C=$ Pruning 14 days after pollinationD $=$ Pruning 21 days after pollination. The result of the research showed that the male flower pruning after pollination of the effect on corn yield and yield components such as Weight, Length and Diameter of Tonggol both without and with kelobot. Sweet corn plants that are not exposed to male flower pruning have the same result and yield components as the plants that are trimmed by their male flowers.

Keyword: Sweet Corn, Pruning Time, Male Flower
\end{abstract}

\section{ABSTRAK}

Telah dilaksankan penelitian bertempat di kebun percobaan Fakultas Pertanian Unwim yang memiliki ketinggian tempat $850 \mathrm{mdpl}$. Penelitian ini bertujuan untuk mengetahui efektivitas waktu pemangkasan bunga jantan terhadap peningkatan komponen hasil dan hasil jagung manis. Rancangan lingkunganyang digunakan adalah rancangan acak kelompok yang terdiri dari : $\mathrm{A}=$ Tanpa pemangkasan $\mathrm{B}=$ Pemangkasan 7 hari setelah penyerbukanC $=$ Pemangkasan 14 hari setelah penyerbukanD $=$ Pemangkasan 21 hari setelah penyerbukan. Hasil penelitian menunjukkan bahwa pemangkasan bunga jantan setelah penyerbukan mempengaruhi terhadap komponen hasil dan hasil tanaman jagung seperti Bobot, Panjang dan Diameter Tonggol baik tanpa maupun dengan kelobot. Tanaman jagung manis yang tidak mengalami pemangkasan bunga jantan memiliki komponen hasil dan hasil terendah dibandingkan dengan tanaman yang dipangkas bunga jantannya.

Kata Kunci : Jagung Manis, Waktu Pemangkasan, Bunga Jantan

\section{PENDAHULUAN}

Permintaan pasar terhadap jagungmanis terus meningkat seiring dengan permintaan pasar modern seperti swalayan, toserba dan mall yang senantiasa membutuhkan jumlah yang relatif besar, belum lagi pada hari - hari tertentu seperti malam tahun baru kebutuhan akan jagung manis meningkat cukup tajam. Peningkataan permintaan ini karena dipengaruhi oleh beberapa keunggulan yang dimiliki jagung manis diantaranya memiliki rasayang lebih manis, aroma lebih harum, danmengandung gula sukrosa serta rendahlemak sehingga baik dikonsumsi bagipenderita diabetes (Putri, 2011).

Permintaan pasar yang cukup tinggi merupakan salah satu faktor yang mengacu dan peluang yang cukup besar bagi petani untuk mengembangkan usaha budidaya jagung manis.Namun peluang ini belum dimanfaatkan sepenuhnya oleh petani Indonesia. Karena disebabkan oleh beberapa hal salah satunya adalah produktivitas yang masih rendah dan kurangnya pengetahuan petani akan informasi pasar yang ada. 
Produktivitas jagung manis di dalamnegeri masih rendah dibandingkan dengannegara produsen akibat sistem budidayayang belum tepat (Palungkun dan Asiani,2004). Produktivitas jagung manis diIndonesia rata-rata 8,31 ton/ha(Muhsanati, Syarif, Rahayu, 2006).Potensi hasil jagung manis dapatmencapai 14-18 ton $\mathrm{ha}^{-1}$.

Produktivitas jagung manis diukur berdasakan bobot tongkol yang mana tersusun atas biji - biji di dalamnya. Biji jagung mempunyai kemampuan untuk menimbun bahan kering. Hal ini merupakan salah satu faktorpenting dalam proses produksi, aspek fisiologis yang mempengaruhi perkembangan biji belum banyak dibahas. Perkembangan biji jagung dipengaruhi oleh beberapa hal antara lain adalah kondisi tanaman sebelum berbunga dan kondisi tanaman setelah berbunga.

Pemotongan bunga jantan (deta seling) pada saat pembuahan tanaman jagung belum diketahui pengarunya secara nyata, namun berdasarkan hasil penelitian yang telah dilakukan oleh Lupton, 1966 ; Wardlaw, 1968 Gardner dkk., 1991 dikutip Surtinah (2005) melaporkan bahwa daun-daun sebelah bawah tanaman gandum dan barli memasok kebutuhan batang sebelah bawah dan akar. Apabila daun-daun pucuk dibuang, daun-daun sebelah bawah akan memasok hasil asimilasi ke biji; bila daun-daun sebelah bawah dibuang, daun bendera akan mentrasfer hasil asimilasi ke akar ( Marshall dan Wardlaw, 1973 ).

Selain itu, Jones and Simmons ( 1983dikutip Borras, 2001 ) menemukan bahwa berat biji tidak dipengaruhi oleh meningkatnya penggunaan asimilat per biji, namun berat biji dipengaruhi oleh berkurangnya jumlah biji per tanaman pada akhir periode pembuahan. Sebaliknya Kiniry $d k k(1990$ ) melaporkan bahwa berat biji-biji pada posisi tongkol yang sama menigkat dengan berkurangnya jumlah biji per tanaman.

Berdasarkan hal tersebut kiranya perlu diteliti lembih lanjut apakah pemangkasan bunga jantan berpengaruh terhadap asimilisai yang terjadi pada biji sehingga mempengaruhi terhadap hasil tanaman jagung manis.

\section{METODE PENELITIAN}

Penelitan dilaksanakan di kebun percobaan Fakultas Pertanian Universitas Winaya Mukti dengan ketinggian tempat 850 mdpl.Curah hujan termasuk tipe $\mathrm{C}$ yaitu agak basah berdasarkan metode smith and perguson. Jenis tanah adalah andisol. Alat dan bahan yang dipergunakan meliputi : cangkul, tugal, meteran pita $1 \mathrm{~m}$, timbangan berkapasitas $2 \mathrm{~kg}$, gunting stek, mistar $30 \mathrm{~cm}$, jangka sorong, pisau, laptop, program SPPS versi 10.0, ajir, pupuk kandang, pupuk urea, SP-36, KCl, fungisida Dithane $M-45$, Sevin 85 benih jagung varietas sweet corn. Penelitian menggunakan Rancangan Acak Kelompok pola sederhana yang di ulang sebayak 6 kali. Pengujian dilakukan dengan menggunakan analisis varian dengan uji beda rata -rata Duncant pada taraf nyata $5 \%$. Perlakuan yang dicobakan berupa pemangkasan bunga jatan dengan taraf sebagi berikut: $\mathrm{A}=$ Tanpa pemangkasan, $\mathrm{B}=$ Pemangkasan 7 hari setelah penyerbuka, $C=$ Pemangkasan 14 hari setelah penyerbukan, $\mathrm{D}=$ Pemangkasan 21 hari setelah penyerbukan

Penanaman dilakukan setelah tanaman diratakan dengan menggunakan cangkul yang sebelumnya telah diberikan pupuk kandang dengan dosis 10 ton $\mathrm{ha}^{-1}$ dengan cara dilarik sepanjang jaraj tanam dalam barisan. Benih ditanam setelah satu minggu pemberian pupuk organik dengan cara ditugal dengan kedalaman $3 \mathrm{~cm}$ dan setiap lobang diisi 2 biji. Satu minggu setelah penanaman dilakukan penjarangan sehingga tinggal satu tanaman setiap lubang tanam. Bersamaan dengan penjarangan dilakukan penyulaman pada tanaman yang tidak tumbuh, tumbuh tidak normal dan terserang hama penyakit. Pemupukan dan pembumbnan dilakukan setelah tanaman berumur tiga minggu. Pemupukan dilakukan dengan menggunakan dosis anjuran 400 $\mathrm{kg}$ urea, $300 \mathrm{~kg}$ SP-36 dan $250 \mathrm{~kg} \mathrm{KCl}$ per Hektar. Pupuk urea diberikan sepertiga bersamaan dengan pembumbunan dua pertiga ketika menjelang berbunga.Sedangkan pemberian pupuk kalium dan fosfor diberikan saat penanaman. 
Aplikasi pemupukan dilakukan dengan cara ditugal dikedua sisi tanaman dengan jarak $5 \mathrm{~cm}$ dari tanaman. Pencegahan hama penyakit dilakukan dengan penyemprotan dengan menggunakan azodrin 15 WSC dan Dithane M-45 sesuai dengan dosis anjuran. Interval dilakukan sesuai dengan intensitas serangan hama dan penyakit. Adapun parameter yang diamatai dalam penelitian ini meliputi: bobot tongkol berkelobot, bobot tongkol berkelobot, panjang tongkol, diameter tongkol berkelobot dan diameter tongkol tanpa kelobot.

\section{HASIL DAN PEMBAHASAN}

Berdasarkan hasil analisis statistik menunjukkan bahwa pengaruh pemberian pemangkasan bunga jantan berpengaruh terhadap bobot tongkol berkelobot per per tanaman.Selanjutnya hasil uji duncant pada taraf nyata $5 \%$ tersaji pada Tabel 1 . Terlihat bahwa perlakuan A (tanpa pemangkasan) memberikan bobot tongkol berkelobot per tanaman terendah dan berbeda nyata dengan perlakuan $\mathrm{C}$ (pemangkasan 21 hari setelah tanam) yang memberikan bobot tongkol berkelobot per tanaman tertinggi. Perlakuan $\mathrm{C}$ tidak berbeda nyata dengan perlakuan B dan D. Perlakuan A (tanpa pemangkasan) memberikan bobot tongkol tanpa kelobot per tanaman terendah dan berbeda nyata dengan perlakuan D (pemangkasan 21 hari setelah tanam) yang memberikan bobot tongkol berkelobot per tanaman tertinggi.Perlakuan $\mathrm{D}$ tidak berbeda tidak nyata dengan perlakuan B dan C. Perlakuan A (tanpa pemangkasan) memberikan panjang tongkol terendah dan berbeda nyata dengan perlakuan D (pemangkasan 21 hari setelah tanam) yang memberikan panjang tongkol tertinggi.Perlakuan D tidak berbeda tidak nyata dengan perlakuan B dan C. Perlakuan A (tanpa pemangkasan) memberikan diameter tongkol berkelobot terendah dan berbeda nyata dengan perlakuan $\mathrm{D}$ (pemangkasan 21 hari setelah tanam) yang memberikan diameter tongkol berkelobot tertinggi.Perlakuan D tidak berbeda tidak nyata dengan perlakuan B dan C. Perlakuan A (tanpa pemangkasan) memberikan diameter tongkol tanpa kelobot terendah dan berbeda nyata dengan perlakuan D (pemangkasan 21 hari setelah tanam) yang memberikan diameret tongkol tanpa kelobot tertinggi.Perlakuan D tidak berbeda tidak nyata dengan perlakuan $\mathrm{B}$ dan $\mathrm{C}$.

Tabel 1.Rata - rata Bobot Tongkol Berkelobot, Rata-rata Bobot Tongkol TanpaKelobot, Rata-rata Panjang Tongkol, Rata-rata Diameter Tongkol Berkelobot DAN Rata-rata Diameter Tongkol Berkelobot per Tanaman akibat Pemangkasan Bunga Jantan pada waktu yang berbeda.

\begin{tabular}{|c|c|c|c|c|c|c|c|c|}
\hline Perlakuan & $\begin{array}{c}\text { Rata-rata } \\
\text { Bobot Tongkol } \\
\text { Berkelobot (g) }\end{array}$ & $\begin{array}{c}\text { Rata-rata Bobot } \\
\text { Tongkol } \\
\text { TanpaKelobot } \\
\text { (g) }\end{array}$ & $\begin{array}{c}\text { Rata-rata } \\
\text { Panjang } \\
\text { Tongkol } \\
\text { (g) }\end{array}$ & & $\begin{array}{c}\text { Rata-rata } \\
\text { Diameter } \\
\text { Tongkol } \\
\text { Berkelobo } \\
\text { (g) }\end{array}$ & & $\begin{array}{c}\text { Rata-rata } \\
\text { Diameter } \\
\text { Tongkol } \\
\text { Berkelobo } \\
\text { (g) }\end{array}$ & \\
\hline \multirow{4}{*}{$\begin{array}{l}\text { A = Tanpa Pemangkasan } \\
B=\text { Pemangkasan } 7 \text { hari } \\
\text { setelah peyerbukan } \\
C=\text { Pemangkasan } 14 \text { hari } \\
\text { setelah penyerbukan } \\
D=\text { Pemangkasan } 21 \text { hari } \\
\text { setelah penyerbukan }\end{array}$} & $359,75 \quad \mathrm{a}$ & $265,92 \mathrm{a}$ & 17,38 & $\mathrm{a}$ & 265,92 & $\mathrm{a}$ & 265,92 & $\mathrm{a}$ \\
\hline & $422,50 \quad a b$ & $332,50 \mathrm{~b}$ & 20,00 & b & 332,50 & b & 332,50 & b \\
\hline & $467,50 \quad b$ & $377,50 \mathrm{~b}$ & 20,50 & b & 377,50 & b & 377,50 & $\mathrm{~b}$ \\
\hline & $445,00 \quad b$ & $365,00 \mathrm{~b}$ & 21,00 & b & 365,00 & b & 365,00 & b \\
\hline
\end{tabular}

Keterangan: Angka rata - rata yang diikuti huruf yang sama pada kolom yang sama berbeda tidak nyata berdasarkan uji rata - rata jarak berganda duncant padataraf nyata $5 \%$. 
Hasil penelitian pemangkasan bunga jantan menunjukkan pengaruh terhadap komponen hasil dan hasil jagung manis. Dimana perlakuan A merupakan perlakuan yang memberikan hasil terendah dibandingkan dengan perlakuan yang dilakukan pemangkasan bunga jantan pada semua waktu yang berbeda.

Tanaman yang tidak mengalami pemangkasan memiliki bobot, panjang dan diameter terendah hal ini terjadi karena bunga jantan setelah mengalami pembuahan tidak langsung mengalami kematian sehingga membutuhkan hasil fotosintat untuk proses pertumbuhannya yang menimbulkan kopetisi di antara tanaman itu sendiri terhadap fotosintat yang dihasilkan. Tidak terpusatnya hasil fotosintesis menyebabkan pembentukan biji menjadi terhambat. Hal ini sesuai dengan pendapat Jones dan Simmons (1983) dikutip Surtinah (2005), yang melaporkan bahwa berkurangnya suplai asimilat yang terjadi sebelum dan sampai awal perkembangan biji menyebabkan terganggunya pembesaran sel embrio dan endosperm.

Tongkol pada tanaman jagung berfungsi sebagai sink (limbung) dimana fotosintat yang dihasilkan dari daun (sourse) akan ditranlokasikan ke dalam tongkol sehingga perkembangan tongkol sangat bergantung pada organ fotosintesis yang aktif setelah pembungaan. Semakin besar aktivitas fotositesis yang terjadi maka akan semakin besar aliran fotosintat yang tesimpan di tongkol yang memungkinkan ukuran biji jagung besar dan bernas.Hal ini sejalan dengan Fauziati dan Raihan (1995) dikutip Caswa Sulaeman (2004) bahwa pemangkasan bunga jantan juga dapat meningkatkan hasil karena peran pemangkasan terutama dalam efisiensi pemanfaatan radiasi matahari dalamimbangannya dengan hasil jagung.

\section{KESIMPULAN}

Berdasarkan hasil penelitian dan penjelasan di atas maka dapat dismpulkan bahwa pemangkasan bunga jantan setelah penyerbukan mempengaruhi terhadap komponen hasil dan hasil tanaman jagung seperti Bobot, Panjang dan Diameter Tonggol baik tanpa maupun dengan kelobot. Tanaman jagung manis yang tidak mengalami pemangkasan bunga jantan memiliki komponen hasil dan hasil terendah dibandingkan dengan tanaman yang dipangkas bunga jantannya.

\section{Saran}

Perlu adanya penelitian lebih lanjut pada kondisi yang berbeda terutama kaadaan iklim.Karena penyerbukan tanaman jagung diperngaruhi oleh keadaan angin.Selain itu perlu dilakukan penelitian yang dikombinasikan dengan jarak tanam supaya diketahui jarak tanam yang efektip dengan pemangkasan yang tepat. 


\section{DAFTAR PUSTAKA}

Surtinah. 2005. Hubungan Pemangkasan Organ bagian Atas Tanaman Jagung ( Zea mays, L ) dan Dosis Urea terhadap Pengisian Biji. Jurnal Ilmiah Pertanian Vol. 1 No. 2.

Putri,H.A. 2011. Pengaruh PemberianBeberapa Konsentrasi PupukOrganik Cair Lengkap (POCL)Bio Sugih Terhadap Pertumbuhandan Hasil Tanaman Jagung Manis(Zea mays saccharata Sturt.).Skripsi. Fakultas Pertanian.Universitas Andalas Padang.48hal.

Palungkun, R. dan B. Asiani. 2004.Sweet CornBaby Corn : PeluangBisnis, Pembudidayaan danPenanganan Pasca Panen.Penebar Swadaya. Jakarta, 79 hal.

Muhsanati, Syarif, dan Rahayu. 2006.Pengaruh Beberapa TakaranKompos Tithonia terhadapPertumbuhan dan Hasil TanamanJagung Manis(Zea MaysSaccharata). Jurnal Jerami VolumeI (2) : 87-91.

Marshall, C., dan I. F. Wardlaw, 1973. Aust. J. Biol. Sci. $26: 1-13$.

Mondal, M. H., W. A. Brun, dan M. L. Brenner, 1978. Plant Physiol. 61 : 394 - 97.

Borras, L., M. Otegui, 2001. Maize kernel weight response to postflowering source - sink ratio. Crop Sci. 49 : 1816 - 1822.

Kiniry, J. R., C. A. Wood, D. A. Spanel, dan A. J. Bockhoft, 1990. Seed weight respons to decreased seed number in maize. Agron. J. 54 : $98-102$.
Caswa Sulaeman. 2004. Pemangkasan Bunga Jantan Dalam Mengendalikan Hama Penggerek Batang Jagung Di Lahan Kering Beriklim Basah.Prosiding Temu Teknis Nasional Tenaga Fungsional Pertanian Tahun 2004. Pusat Penelitian dan Pengembangan Peternakan 
32 |PASPALUM Volume 5 Nomor 1 Maret 2017 